\title{
Workington: a case study in coordination and communication
}

\section{Arthur Affleck PhD}

Research Associate, i-BUILD, Newcastle University, NUBS, Newcastle upon Tyne, UK

\author{
Jane Gibbon PhD \\ Senior Lecturer in Accounting, Newcastle University Business School, \\ Newcastle upon Tyne, UK
}

This study was carried out to identify the social impact of losing transport links within a community, and the practices of coordination and communication during and after an extreme adverse event. In November 2009, Workington, Cumbria had most of its bridges either damaged or destroyed during a major flood. The effects of the disaster were immediate, while the subsequent planning and recovery process took time. Over 3 years, Cumbria County Council (CCC) went through a coordinated process of installing temporary infrastructure, building and repairing Workington's bridges. A desk-based investigation of the disaster and the recovery process using websites and the local press demonstrates a coordinated approach to replace Workington's infrastructure and the importance of communication in the town's recovery. CCC, through a series of practical measures, reduced disruption within the community in stages. The reconstruction of the town's bridges involved communication and public consultation about the new infrastructure. The CCC explained the design, financial and engineering elements of the bridges to the public with some success. The research found that the loss of each bridge had significant social impacts, and the coordinated actions and communication of CCC helped the community understand and, importantly, accept that reconstruction would not be immediate.

\section{Introduction}

In November 2009, Workington, Cumbria had the majority of its bridges either damaged or destroyed during a major flood. Over the next 3 years, Cumbria County Council (CCC) and their contractors replaced the infrastructure with temporary bridges and then permanent bridges. This paper examines the issues that emerged during rebuilding the town's bridges. CCC was tasked with coordinating and communicating the recovery process to the regional population. The paper is in four sections. Section 2 includes background such as the methodology, governance and a narrative of the events as they unfolded. Section 3 focuses on the different forms of recovery such as using existing infrastructure and communicating the processes of rebuilding bridges. Section 4 discusses how CCC communicated with the public and assesses the public reaction. Finally, conclusions and recommendations derived from the research are discussed in Section 5.

\section{Background}

\subsection{Methodology}

This paper uses the methodology of a social account to examine the processes of communication and the approach to coordination used during reconstruction. The methodology identifies the different groups or organisations affected by the disaster and involved in the recovery as stakeholders. In this retrospective case study, CCC was the governance body, while Allerdale Borough Council, the contractors and the local population and business were all stakeholders involved in the recovery of Workington's transport infrastructure. This deskbased study gathered materials found on the Internet such as news stories, both regional and national, public documents, engineering information and public comments in the local press. The research covers the period from November 2009 to 2013. The online versions of local newspapers, such as the News and Star, contained over 200 articles about the rebuilding of Workington's bridges. CCC's website held pages about the funding, procurement of contractors and construction of the bridges. Using Internet sources has been recognised as an opportunity for social science research (Bryman, 2012). Over 450 news articles, reports, documents - such as procurement tenders and planning applications - were gathered, collated and analysed to form a social account of the recovery process. The collating process involved recording the date, the source, the title, which bridge the type of article or document, and the number and nature of public comments within a database. The articles and documents were categorised by type such as consultation, procurement, funding, the building process and technical information. The database allowed the news stories and documents to be arranged chronologically and divided into different categories. All of the news articles and documents about each bridge could be put together in a 
spreadsheet and analysed. This methodology produces a chronological narrative for each bridge and each issue such as funding or procurement.

The use of different forms of social accounts to investigate organisations using publicly available material and newspaper stories is nothing new (Dey, 2003, 2007; Gray, 1997). By examining Internet sources, the research has identified how communication occurred. CCC were posting information onto their website and issuing news releases. While the local newspaper, The News and Star, used CCC's press releases and produced their own news stories. The online newspaper gave the local residents the opportunity to comment on the rebuilding process online. The residents were given a voice to be positive, negative or neutral about CCC's governance of the recovery process. Over a 3-year period, around 1000 comments were posted about the bridges.

The range of information gathered from the $\mathrm{CCC}$ website, Department for Transport (DfT), BBC news, the local newspapers, New Civil Engineer (NCE) and other specialist sources strengthens the methodology. During the flood and resulting traffic problems, CCC issued 79 news and travel updates from 18 to 30 November 2009. The frequency of news updates diminished as the situation moved from an emergency to a recovery process. The acknowledged limitations are that some web pages no longer exist and public comment is only from those with access to the Internet; therefore, the information is not completely representative.

\subsection{Governance}

CCC chaired the Cumbria Flood Recovery Co-ordinating Group with key partners such as Allerdale Borough Council, the Environment Agency, National Health Service Cumbria, Government Office for the North West, the emergency services and nearly 50 agencies were involved in the recovery groups. CCC was both the governing body and a stakeholder in the recovery process which was broken into four groups: welfare, business and economy, environment, and infrastructure and transportation. CCC had other partners, such as Capita Symonds, who in 2001 had absorbed the Council's Design and Business Services consultancy team (Capita, n.d.-a). This external transfer included over 300 property and infrastructure professionals and meant that Capita Symonds inspected, assessed and made safe bridges, retaining walls, highways and drainage infrastructure (Capita, n.d.-b). CCC had also contracted both Amey (CCC, 2011a) and Balfour Beatty to maintain parts of their highway infrastructure (CCC, 2011b).

CCC was an important stakeholder with a key role in the governance of the recovery process involving the coordinating and communicating of measures to rebuild the town's infrastructure. Workington's residents and businesses were also key stakeholders affected by the loss of the bridges. Other stakeholders were organisations involved in the recovery process such as the central government, the DfT and the contractors. CCC had to coordinate and communicate with all stakeholders.

\subsection{Narrative of events}

On 18 November 2009, Cumbria was warned of heavy rain and the county had six severe flood warnings in Keswick, Cockermouth, Eamont Bridge, Southwaite and Burneside. Floods occurred across the region, including Workington. In the town, the Northside Bridge collapsed into the River Derwent killing a policeman, the Calva Bridge was unsafe and closed, and the Navvies Bridge was washed away. Allerdale was badly affected with floods in Cockermouth, Keswick and Workington. During this time, Gold Command, made up of emergency services and partners such as CCC, was assembled to manage the immediate effects of the floods from 19th November and operations were scaled down from 23 November 2009 (CCC, 2009). After the emergency period, $\mathrm{CCC}$ took on the task of recovery.

After the flood, Workington only had one piece of infrastructure - the railway bridge linking the north with the south of the town. Most schools were now separated from some of their pupils' residential areas, with $90 \%$ of the population living south of the river. Conversely, many residents in the north were employed in the centre of the town in the south (Guiver, 2011). Initially, travelling from north to south Workington took a 40-mile $(64 \mathrm{~km})$ diversion because the Papcastle Bridge near Cockermouth was temporarily closed. Media reports stated that with no bridges, the residents of Workington were making 18-21-mile $(28-33 \mathrm{~km})$ detours to reach their work place; journeys that previously took $15 \mathrm{~min}$ were now taking up to $2 \mathrm{~h}$ due to congestion as traffic converged from a few routes onto one bridge. The loss of the bridges resulted in immediate social and economic impacts, and the response of residents was to make fewer journeys by car (Guiver, 2011). Table 1 shows the timeline for the failure of infrastructure, the initial emergency period and the 3-year recovery process.

\section{Workington's recovery}

\subsection{Utilising existing infrastructure}

CCC and its partners identified solutions to link the north and south of the town. The railway bridge was assessed and found to be the only safe crossing in Workington. The railway bridge was utilised in two ways. First, over 1000 telephone lines were diverted from the damaged Calva Bridge across this bridge. After the loss of Workington's road and pedestrian bridges, there was a large increase in people using the train to get from Workington Station to Flimby Railway Station across the 
Timeline - the emergency and recovery of Workington

18 November 2009

19 November 2009

20 November 2009

30 November 2009

1-7 December 2009

21 April 2010

14 May 2010

21-22 September 2010

8 October 2010

February 2011

March 2011

10 September 2011

22 October 2012
The Environment Agency warns of heavy rain and risk of flooding across parts of Cumbria

Gold Command set up to manage the initial emergency and was scaled back after 23 November 2009

The floods destroy a footbridge (the Navvies) and a road bridge (the Northside); another road bridge

(the Calva) was damaged and closed for repairs; across Cumbria, three road bridges were lost

completely and another 17 were temporarily closed due to structural damage

Temporary train station opened on the north of Workington linking both parts of the town

The RE assemble and open a temporary foot bridge called Barker Crossing

Temporary road bridge opened

People are invited to a drop-in session at Workington's Carnegie Theatre to share their views about the replacement bridges

Two public meetings to discuss designs for the new bridges

Closure of temporary train station

Closure of Barker Crossing and the opening of Calva Bridge to pedestrians

Reopening of Calva Bridge to traffic

New footbridge opened to replace the Navvies bridge

Opening of new Northside Bridge and closure of temporary road bridge

Table 1. Timeline for the failure of infrastructure, the initial emergency period and the 3-year recovery process of Workington

River Derwent (News and Star, 2009). Second, the railway bridge could be better utilised by building a train station in north Workington. Network Rail found a location owned by Allerdale Borough Council with access to the road network and sufficient space for platforms and car parking. The station took $6 \mathrm{~d}$ to be built. The DfT funded the station and Northern Rail ran a free hourly service linking the two parts of the town. The bus timetable was coordinated with the train times to improve travel. At its peak time, the station was being used by 2000 passengers per day, but as recovery progressed and bridges were opened there were fewer passengers and it closed in October 2010 (NR, 2010).

\subsection{Constructing temporary infrastructure}

\subsubsection{Footbridge - Barker Crossing}

The building of the bridge illustrated a clear command structure, construction knowledge and expertise, and the ability of local agencies to work together after a disaster (Livesey, 2011). The County and Borough councils and the army were brought together as stakeholders to build a temporary footbridge, Barker Crossing. This bridge was named after PC Bill Barker, who had died during the floods. As part of CCC's Recovery Group, a team from the Corps of Royal Engineers came to Cumbria to assess whether the military could help the Workington community. They began by surveying different sites. A significant issue for the construction was that the foundations of the old Northside Bridge were badly damaged (Hansen, 2009). The Royal Engineers (RE) knew they needed a site with a large construction area and that land ownership could be an issue; they found a suitable site owned by Allerdale Borough Council. The RE tested the site to assess the abutment design. They decided on the logistic support bridge (LSB), developed from the Bailey Bridge and foundation design. During the design phase, there were discussions between stakeholders about the load the bridge should carry and eventually it was decided that the bridge would be pedestrian. The LSB superstructure could carry a load of 40 tonnes, but the abutments were not suitable for regular trafficking of large vehicles. The RE could have built stronger abutments to take vehicles, but not within the given time frame (Livesey, 2011). Previously, the Calva Bridge and Northside Bridge were used by 37000 vehicles daily (CCC, 2010), and during November a small number of drivers had illegally used the closed Calva Bridge; therefore, the decision was made to prevent vehicle access to the temporary bridge (Livesey, 2011). The BBC reported that construction of the foundations for a vehicle bridge would take a much longer time. CCC, contractors and RE communicated well, and worked $24 \mathrm{~h} / \mathrm{d}$ to achieve a $10 \mathrm{~d}$ construction time; the local and national press praised their work.

The bridge relieved some of the town's infrastructure problems and was used by up to 35000 pedestrians per week. School and regular buses stopped close to the bridge, giving the town another link. This solution was not without problems and to avoid accidents and congestion, drivers were unable to use the access roads leading to the footbridge. Some motorists ignored this guidance and within a month 50 motorists were fined for using these roads (Barwise, 2010a). Public transport from the 
temporary station and the footbridge offered a transport solution, but residents wanted a road bridge to be built.

\subsubsection{A road bridge}

After the floods, CCC had to negotiate with the DfT for funding for a temporary road bridge. In December 2009, Minister for Transport, Sadiq Khan, announced there was government funding for a temporary road bridge. The procurement process started and CCC requested expressions of interest to construct the temporary bridge; of the 12 respondents, 3 were short listed. Even though the procedures seemed to be moving quickly, the NCE reported that the procedure was held up due to EU Procurement Directives, with the intended winning contractor having to wait $10 \mathrm{~d}$ in case the other companies wished to mount a legal challenge if they felt the process was unfair or discriminatory (Hansford, 2010). To speed up this process and start the building of the temporary road bridge, CCC had a separate contractor investigating the site for designing the foundations, to begin drilling boreholes and connecting with the road system. CCC allowed the work to be done $24 \mathrm{~h} / \mathrm{d}$ and $7 \mathrm{~d}$ a week to speed up the process. A contractor was chosen and a temporary bridge was brought over from Holland. The bridge opened on 21 April 2010 at a cost of around $£ 4.6$ million. The bridge and connecting highways did not have the capacity to be used by all vehicles at peak times. CCC had the difficult job of deterring drivers from using the bridge to avoid congestion. They sent out postcards, used the local press and held a dropin session to encourage people to use public transport, cycle/ walk or car share. With the road bridge now open, CCC announced that the buses were returning to preflood timetables and new traffic diversions were in place. The attempt of the $\mathrm{CCC}$ to coordinate the opening of the bridge and its daily use can be seen as that of managing expectations since one road bridge would have difficulty in replacing two bridges.

\subsubsection{Communication with the community}

Communication was an important element of the recovery process and in December 2009 CCC announced that it would be 2 years before replacement bridges were completed. CCC explained in the local press that there was a design stage and tendering process. Their engineers had produced six options for temporary and permanent bridges, which were submitted to the DfT. At this point, $\mathrm{CCC}$ did not know if the Calva Bridge could be saved; therefore, it had to consider two replacement road bridges and find funding. Meanwhile, the public were concerned about the time it was taking to find a solution. In February 2010, the News and Star announced there would be a decision about the Calva Bridge as residents were anxious about its future (Barwise, 2010b). In May 2010, after extensive structural analysis it was announced that the bridge could be repaired (Lynch, 2010) and repairs were begun in the following month (CCC, n.d.).
After the temporary road bridge opened, CCC began asking the public about the proposed replacement of Navvies and Northside bridges. The public were asked their opinions about the new bridges at two drop-in sessions in May and two public meetings in September 2010 (BBC, 2010). The feedback showed that the community wanted safer bridges that were either a single span or suspension bridge. The respondents wanted the original sandstone blocks to be reused where possible and were clear that they valued the heritage of the area (ABC, 2010). Equally, they were concerned about parts of the Northside Bridge being dismantled and stone blocks being pulverised. People wanted local supply chains and employment within the town. Previous work has found that community participation with infrastructure projects will not produce a homogeneous group with common goals (Mulligan et al., 2011). In Workington's case, for some people the proposed replacement bridges should be iconic, something different, built of sandstone, constructed of steel, pedestrian friendly and beautiful, while some just wanted the bridges to be built quickly (ABC, 2010).

CCC and their partners accepted public views on the use of steel and reuse of sandstone blocks from the original bridge. The planning applications for the Navvies and Northside bridges also gave organisations and individuals another opportunity to comment on the designs.

\subsection{Constructing permanent infrastructure}

\subsubsection{The Navvies Bridge}

After the consultation process, the next bridge to be built was the permanent Navvies Bridge for pedestrians and cyclists. The local press reported that the CCC had redirected funds to the new bridge. The cost of the bridge was $£ 1.7$ million - with $£ 1.06$ million coming from CCC; the Nuclear Decommissioning Authority contributed $£ 100000$ and $£ 375000$ from the Big Lottery Fund through Sustrans. CCC's website stated that the contractor was selected in November 2010 and work due to begin in January 2011. Originally, the bridge was to open in April, but this was put back until September 2011. Some preliminary work was started moving utilities and clearing vegetation. Legal and technical issues delayed the process and the award of the construction contract to Morgan Sindall. CCC brought in Morgan Sindall as the managing contractor, Yee Associates as architects, Rowecord Engineering as fabricator and Capita Symonds as designer of the substructure (Rowecord, n.d.). The $150 \mathrm{t}, 68 \mathrm{~m}$ long, steel bow-arch structure was assembled on site and lifted into position. With the addition of this bridge, the town now had two footbridges and a temporary road bridge.

\subsubsection{The Calva Bridge}

During the floods, the central pier of the three-span Calva Bridge was partially washed away. Initially, the Grade II listed 
bridge was condemned. In May 2010, the NCE reported that the Calva Bridge had an extensive structural analysis and the central pier was to be underpinned and repaired (Lynch, 2010). The public wanted the bridges to be made of stone, so the repair was done with ashlar stone to match the existing facade (Lynch, 2010).

The Calva Bridge was opened to pedestrians in February and vehicles in March 2011. Once this bridge was reopened, the temporary footbridge built by the RE was closed and dismantled. Evidence from the CCC's website and local press demonstrates it was looking for funding to repair or replace the bridge. Eventually, the financing of the repair was through the Carlisle Northern Development Route operation and the maintenance contract with Balfour Beatty (CCC, n.d.).

\subsubsection{Northside Bridge}

In 2009, CCC announced that the permanent road bridge would take 2 years to be built. In the local press, a representative of CCC stated 'We have the design stage, tendering, letting contracts and then construction. We don't think two years is an unrealistic timescale' (Whittle, 2009). In March 2010, CCC's development control and regulation committee gave the go ahead to replace the road bridge that was destroyed in the floods and proposed to have a replacement bridge in place by May 2012. Later, the Council announced in the local press that due to piling issues, severe weather conditions and the limited availability of cranes, the opening of the new road bridge would be delayed for 5 months. In the local media, this announcement received 12 comments from the public, 6 were positive defending the building process, accepting there could be delays with bad weather and wanting strong foundations. One person had researched the original bridge and found it took over 10 years to get funding, 5 years in planning and 4 years in construction; so the replacement was faster (News and Star, 2012). Within infrastructure projects, it is important to keep a community informed and not to withhold sensitive information (Kalowski, 2008), and CCC managed expectations by keeping the public informed of the delay.

The Northside Bridge had a series of complex and interdependent issues to resolve such as finance, public opinion, landowners and delays due to problems with piling. First, CCC began negotiating about funding with the DfT soon after the floods. In November 2010, CCC issued a tender for the construction of a $152 \mathrm{~m}$, three-span steel and concrete composite bridge. Subsequently, submitted the planning application in December 2010. The bridge was an improvement on the original, being $5 \mathrm{~m}$ wider to incorporate $2.5 \mathrm{~m}$ footpaths and $1.5 \mathrm{~m}$ for highway cycle ways. The planning process did take into account the opinions of the public and experts; for example, three viewing platforms were removed from the plan after objections from the public and comments from the Police Architectural Liaison Officer (CCC, 2011c).

In March 2011, CCC granted planning permission and DfT agreed that the bridge was in a high Value for Money category and did not have to go through the same processes as other infrastructural projects. The DfT did not produce a benefitcost ratio estimate due to the exceptional circumstances caused by the flood. However, in May, CCC announced that the construction process could be delayed by 2 years because one of the nine landowners around the site would not allow the council to use their land. This produced a number of news stories in the local press with 39 public comments made on one. Agreement was later achieved and the rebuilding process could continue. In June 2011, Local Transport Minister, Norman Baker, gave the go ahead to start construction on the bridge with $£ 11.17$ million funding from the DfT.

Birse Civils, part of Balfour Beatty, won the contract later in the year and with funding in place, the work started in August. The contractors were Capita Symonds as the structural engineers and Mabey Bridge as the chosen steelwork contractor. The construction was delayed due to piling problems, which produced some negative comments from residents. The News and Star explained that Birse Civils had to use the more timeconsuming technique of using fluid in the bored piles prior to adding the concrete (News and Star, 2011). Local residents seem to have accepted the noise and vibrations from the piling process and a resident stated 'They have listened to our side so that makes a difference. We work with them. The quicker we get it up the better' (News and Star, 2011).

The construction process involved 72 bored piles to a depth of $26 \mathrm{~m}$ and the bridge's piers were built on the riverbanks rather than in the river, reducing the amount of working in and over water (New Steel Construction, 2013). Mabey Bridge erected the steelwork in three phases, with the northern section being erected during a weekend in February and the southern section a month later. To avoid working over water, the middle section was made up of six pairs of girders welded into the required lengths. The cantilevering formwork making the deck was installed before the lifting process took place. The middle section of 160 tonnes took three lifts to get in place. The new Northside Bridge was opened in October 2012, which was the final element of rebuilding Workington's infrastructure.

\section{Discussion}

The examination of Workington's recovery through online sources raises a number of issues. The discussion examines CCC's coordination and communication of the recovery process through the news media and what can be learned from collating and analysing Internet materials. 
The quick and coordinated solution in building a temporary railway station and temporary footbridge were praised in both local and national press. There were complex interdependencies with CCC working with British Telecom engineers to redirect cables, the train and bus operators, and also for keeping the public informed about timetables and road closures. Similarly, the RE and the CCC worked successfully together, and the RE senior engineer, Major Grant Kerr, commented the two local councils' 'help has been instrumental' (Stimpson, 2009). The local press reported on the building of Barker Crossing, while the engineering literature provided evidence of problems with the foundations (Livesey, 2011). To provide an account of the building work, there needs to be a range of information from different sources aimed at various audiences.

Within a month of the flood, CCC stated that the temporary road bridge would take 6 months while a permanent road bridge would take 2 years. This announcement received comments in the local press and the majority were negative, highlighting bridges being built quickly in less-developed counties and others used the example of the RE's footbridge as a model that could easily be duplicated for vehicles. However, the foundations for the Barker Crossing footbridge were not strong enough for the amount of traffic. CCC did stress that a vehicle bridge would be a much larger job than a footbridge. CCC responded through the local press, including details of the tender and short-listing processes for the temporary road bridge construction. In the short term, it seems to have been difficult to communicate the funding and legal issues when the public concern was their immediate need for a road bridge.

During the following months, both CCC's website and the local press provided information about the construction of the temporary road bridge. There were 34 comments in the local press when the bridge opened, the majority were neutral and related to bus services and bridge type. The positive comments about the contractors and bridge matched the negative comments. Then, CCC started a consultation process about the new bridges, and continued with media releases about repairing and rebuilding the bridges.

There were fewer media releases for the building and opening of the Navvies footbridge than other bridges, possibly because it was a permanent replacement for the temporary footbridge. However, the uncertainty of repairing or demolishing the Calva Bridge was difficult to both coordinate and communicate, with 31 comments posted in the local press when the possibility of repair was announced. CCC had been looking for funding for replacement bridges, while the engineers were trying to assess whether it could be repaired or not. The local press coverage seemed to ignore the complex repair, while engineering websites explained the repair process in some depth. The announcement that the Calva Bridge would open to traffic earlier than planned resulted in negative comments about the time it took to make a decision; other comments supported CCC and contractors, showing awareness of the complex issues of rebuilding of infrastructure.

If the public are given all the necessary information and time within the planning process, they will reach conclusions that experts would have difficulty overruling (Cohen, 2005). The building of the Northside Bridge provided CCC with the opportunity to consult the public over 2 years and explain the issues involved in building infrastructure. The two-part consultation process in 2010 enabled CCC to gather information about the bridges people wanted, and to draw together ideas and comment on design options. When CCC announced there was a suitable site but there was an issue with one landowner not allowing permission, there was public outcry with 39 comments being posted in the local press. This could have led to a 2-year legal battle, but the unnamed landowner eventually agreed. The issue of landowners illustrates that the process of recovery involves many parties and not just CCC and contractors, with complex interdependencies being difficult to coordinate and communicate. There were delays to the opening of the bridge due to piling issues, severe weather and availability of cranes; the public responded positively accepting there could be delays with bad weather and technical issues. One person had researched that the original bridge took over 10 years to get funding and therefore the time taken to replace it was an improvement. The use of a time-lapse video on YouTube was an effective way to communicate progress on rebuilding the Northside Bridge. The film, posted in April 2012, provided CCC and contractors with an opportunity to counter all the negative images of collapsed bridges and traffic chaos. While there were complaints about the time taken, the public were supportive of the contractors and in understanding of the building process.

The opening of the Northside Bridge attracted national media attention while giving some closure to Workington's infrastructure replacement. Throughout the recovery process, CCC regularly communicated about the temporary infrastructure, while the comments in local media became more supportive and understanding of the complex recovery process. The local press can highlight the issues and problems at a local level, and engineering sources provide evidence of technical issues and solutions. The holistic approach to gathering information from a variety of sources and from the perspectives of the governing body, funder, engineering contractors and public has been brought together to develop a chronological account or narrative of Workington's bridges.

\section{Conclusions}

The process of gathering and analysing the data shows that the recovery process in Workington had complex interdependencies, which include economic, social, environmental, technical, 
political and financial influences. The Workington case study, which involved three bridges and two temporary bridges, is an extreme example of loss of infrastructure and lessons can be learned from this ex-post research using social account methodology to gather data from various sources.

An analysis of the available materials demonstrates that the national media concentrated on the big stories such as the failure of the bridges, the opening of the temporary railway station and the opening of the new bridge. The local newspapers reported on the more immediate everyday life stories after the loss of the bridges and the gradual rebuilding of Workington's infrastructure. The methodology of gathering appropriate news stories, reports and technical documents gives a robust narrative of events, decisions and opinions. The technical sources provide contemporary quotes from the engineers involved in rebuilding the infrastructure (Lynch, 2010; Stimpson, 2009; Wynne, 2009). Similarly, the local press report on the rebuilding process, and include quotes from members of CCC (Barwise, 2010c) and comments from the public (Barwise, 2010a; News and Star, 2012). The justification for making decisions and the comments from the public were made at the time and have not been changed or influenced subsequently.

During the Cumbrian flooding and as bridges were destroyed, CCC produced frequent daily updates. Once the emergency subsided and the recovery process was started, the communication from CCC became less frequent and more planned. Unsurprisingly, during the emergency, the public were not consulted about the temporary station, Barker Crossing or the temporary road bridge. These were coordinated responses to the failure of infrastructure. The plans for new bridges needed both funding and contractors, while the timing allowed communication with the public. Within infrastructure planning, the involvement of the public can be beneficial (Andrew, 2012), and Workington shows that this consultation did occur after the temporary road bridge was in place.

One thing to learn from the Workington case study is to communicate problems even if these are not always acceptable to the public. In December 2009, CCC announced that a temporary road bridge would be built by summer and the permanent road bridge would take 2 years to be built, which produced 39 comments in the local press (Whittle, 2009). By making this announcement, $\mathrm{CCC}$ received some negative comments, but set the agenda for the next 3 years. The region's inhabitants and businesses knew that a permanent replacement was not going to be immediate. This could be understood as managing expectations and being honest about processes involved in building a bridge.

In the comments section of the local newspaper, residents had found examples of bridges in the UK and abroad being constructed in short time periods. A further issue raised by this case study is the complexity of the funding, designing a bridge, the geology of the location, procuring contractors and go through planning procedures. This complexity needs to be adequately communicated to residents and businesses as each location and bridge will be in some way site specific.

Finally, there is public awareness that bridge design is highly specific for a particular location and purpose, with immediate replacement solutions not always being possible. Workington's bridges enable co-use by not only carrying passengers, pedestrians, cyclists and vehicles, but also water and gas mains and telephone cables. Overall $\mathrm{CCC}$ and their partners did succeed in communicating and coordinating to their stakeholders the complex interdependencies of the legal, financial and technical aspects of (re)building Workington's infrastructure over 3 years.

\section{Acknowledgements}

This research was supported by UK Engineering and Physical Sciences Research Council (EPSRC) and Economic and Social Research Council (ESRC), 'iBUILD: Infrastructure Business models, valuation and Innovation for Local Delivery' project (EP/K012398/1). Data supporting this publication is openly available under an 'Open Data Commons Open Database License'. Additional metadata are available at: 10.17634/ 121736-1. Please contact Newcastle Research Data Services at rdm@ncl.ac.uk for access instructions.

\section{REFERENCES}

ABC (Allerdale Borough Council) (2010) Workington Connected: Shaping the Recovery and Building the Future of Workington. Replacing the New/Northside Bridge and Navvies Bridge. Allerdale Borough Council, Workington, UK. See http://www.allerdale.gov.uk (accessed 05/03/2014).

Andrew RM (2012) 'With' and not 'to' - the key to unlocking communities. Proceedings of the Institution of Engineers Municipal Engineer 165(3): 149-156, http://dx.doi.org/ 10.1680/muen.11.00019.

Barwise J (2010a) Fifty fined for driving to Workington Barker Crossing footbridge. News and Star, 9 January. See http://www.newsandstar.co.uk/news/fifty-fined-fordriving-to-workington-barker-crossing-footbridge-1.658832 (accessed 4/8/2014).

Barwise J (2010b) Decision soon on flood damaged Calva Bridge in Workington. News and Star, 11 February. See http://www. timesandstar.co.uk/decision-soon-on-flood-damaged-calvabridge-in-workington-1.671050 (accessed 04/05/2014).

Barwise J (2010c) Plans to be revealed for Workington's damaged bridge. News and Star, 14 May. See http://www. timesandstar.co.uk/decision-soon-on-flood-damaged-calvabridge-in-workington-1.671050 (accessed 04/05/2014). 
BBC (British Broadcasting Corporation) (2010) New Workington bridge plan put before public. BBC News, 8 September. See http://www.bbc.co.uk/news/uk-england-cumbria11229372 (accessed 21/07/2014).

Bryman A (2012) Social Research Methods, 4th edn. Oxford University Press, Oxford, UK.

Capita (n.d.-a) Partnerships. Capita, London, UK. See http:// www.capitasymonds.co.uk/partnerships/cumbria.aspx (accessed 11/08/2014).

Capita (n.d.-b) Cumbria Floods Response. Capita, Carlisle, UK. See http://www.capitasymonds.co.uk/our_expertise/all_ projects/cumbria_floods_response.aspx (accessed 03/08/ 2014).

CCC (2009) November 2009 Floods, Emergency Response Timeline. CCC, Carlisle, UK. See http://www.cumbria.gov. uk/floods/explanationandtimeline/responsetimeline.asp (accessed 03/08/2014).

CCC (2010) Flood Recovery - Roads and Bridges; Frequently Asked Questions (FAQ's). CCC, Carlisle, UK. See http:/l www.blindcrake.org.uk/pdf/Roads $\% 20$ and $\% 20$ Bridges.pdf (accessed 12/09/2014).

CCC (2011a) Council News: 25/8/2011 - Amey Staff Due to Return to County Council Employment. CCC, Carlisle, UK. See http://www.cumbria.gov.uk/news/2011/August/25_ 08_2011-142402.asp (accessed 03/08/14).

CCC (2011b) Council News: 15/11/2011 - Workington (Calva) Bridge Restoration Wins Engineering National Award. CCC, Carlisle, UK. See http://www.cumbria.gov.uk/news/ 2011/November/15_11_2011-151354.asp (accessed 12/09/ 2014).

CCC (2011c) Development Control and Regulation Committee, 23 March, Replacement of Former Northside Bridge. CCC, Carlisle, UK. See http://councilportal.cumbria.gov.uk/ documents/s5908/2109032\%20report\%20dcr\%20110323.pdf (accessed 12/09/2014).

CCC (n.d.) Workington (Calva) Bridge Repair. CCC, Carlisle, UK. See http://www.cumbria.gov.uk/roads-transport/ highways-pavements/cndr/calvabridgerepair.asp (accessed 04/08/2014).

Cohen T (2005) Community involvement in planning: finding a happy medium. Proceedings of the Institution of Civil Engineers - Municipal Engineer 158(1): 5-8, http://dx.doi. org/10.1680/muen.2005.158.1.5.

Dey C (2003) Corporate 'silent' and 'shadow' social accounting. Social and Environmental Accountability Journal 23(2): 6-9.

Dey C (2007) Developing silent and shadow accounts. In Sustainability, Accounting and Accountability (Unerman J, Bebbington J and O'Dwyer B (eds)). Routledge, London, UK, pp. 307-326.

Gray R (1997) The silent practice of social accounting and corporate social reporting in companies. In Building Corporate Accountability: Emerging Practices in Social and
Ethical Accounting, Auditing and Reporting (Zadek S, Evans R and Pruzan P (eds)). Earthscan, London, UK, pp. $20-17$.

Guiver J (2011) Travel Adjustments after Road Closure: Workington. Institute of Transport and Tourism, University of Central Lancashire, Open University, Milton Keynes, UK. See http://clok.uclan.ac.uk/5254/1/GuiverWorkington-2_5254.pdf (accessed 01/02/2014).

Hansen L (2009) Soldiers and engineers working to reunite flooded town. BBC News, 1 December. See http://news.bbc. co.uk/1/hi/uk/8387341.stm (accessed 21/07/2014).

Hansford M (2010) Three firms shortlisted to build temporary road bridge for flood-hit Workington. New Civil Engineer, 16 January. See http://www.nce.co.uk/three-firmsshortlisted-to-build-temporary-road-bridge-for-flood-hitworkington/5212975.article (accessed 05/08/2014).

Kalowski J (2008) Community consultation: lessons from Sydney. Management Procurement and Law 161(2): 65-69.

Livesey C (2011) The barker crossing: royal engineers reconnect Workington. Proceedings of the Institution of Civil Engineers - Civil Engineering 164(2): 81-87, http://dx.doi. org/10.1680/cien.2011.164.2.81.

Lynch D (2010) Cumbria gets stuck into flood repairs. Delicate repair job for Workington's 'condemned' Calva Bridge. New Civil Engineer, 27 May. See https://www.cumbria.gov. uk/eLibrary/Content/Internet/544/3887/5990/40436144419. pdf (accessed 05/09/2014).

Mulligan J, Tompsett AL and Guthrie PM (2011) An 'engineer-client' framework for participation in community-scale infrastructure projects. Proceedings of the Institution of Civil Engineers - Engineering Sustainability 164(1): 35-47, http://dx.doi.org/10.1680/ensu. 2011.164.1.35.

New Steel Construction (2013) Restoring a vital link. New Steel Construction, 21 January, pp. 26-27. See http://www. newsteelconstruction.com/wp/wpcontent/uploads/digi/ 1301NSCJanFeb13/index.html\#/26/ (accessed 05/09/2014). News and Star (2009) Prime Minister Gordon Brown pledges to pay for the temporary bridge. News and Star, 26 November. See http://www.timesandstar.co.uk/prime_ minister_gordon_brown_pledges_to_pay_for_temporary_ bridge_1_640617 (accessed 01/11/2014).

News and Star (2011) Northside gets plenty of good vibrations from building work. News and Star, 3 November. See http://www.newsandstar.co.uk/northside-gets-plenty-ofgood-vibrations-from-building-work-1.894004 (accessed 05/09/2014).

News and Star (2012) Opening date set for Workington's new Northside Bridge. News and Star, 17 August. See http:// www.newsandstar.co.uk/news/opening-date-set-forworkington-s-new-northside-bridge-1.986321 (accessed 05/09/2014). 
NR (Northern Rail) (2010) Temporary Workington

North Station to Close. Northern Rail, York, UK.

See http://www.northernrail.org/news/6515 (accessed 05/09/2014).

Rowecord (n.d.) Project Information Sheet, Navvies Replacement Footbridge. Rowecord, Newport, UK. See http://www.rowecord.com/user_resources/downloads/ Navvies.pdf (accessed 20/06/2014).

Stimpson J (2009) Workington temporary bridge opens for use. New Civil Engineer, 7 December. See http://www.nce.co.uk/ workington-temporary-bridge-opens-for-use/5211746. article (accessed 15/09/2014).

Whittle J (2009) Two years to build permanent new bridges for Workington. News and Star, 9 December. See http://www. newsandstar.co.uk/news/two-years-to-build-permanent-newbridges-for-workington-1.647969 (accessed 05/08/2014).

Wynne A (2009) Workington bridge push reconnects flooded town. New Civil Engineer, 3 December. See http://www.nce. co.uk/workington-bridge-push-reconnects-flooded-town/ 5211582.article (accessed 05/11/2014).

\section{WHAT DO YOU THINK?}

To discuss this paper, please email up to 500 words to the editor at journals@ice.org.uk. Your contribution will be forwarded to the author(s) for a reply and, if considered appropriate by the editorial panel, will be published as discussion in a future issue of the journal.

Proceedings journals rely entirely on contributions sent in by civil engineering professionals, academics and students. Papers should be 2000-5000 words long (briefing papers should be 1000-2000 words long), with adequate illustrations and references. You can submit your paper online via www.icevirtuallibrary.com/content/journals, where you will also find detailed author guidelines. 